\title{
[情報］
}

\section{「みんなのくらしと放射線展」の参加者に対するアンケート 調查から得られた放射線および照射食品に対する意識傾向}

\author{
古田 雅一 \\ 大阪府立大学先端科学研究所 \\ Consumer attitudes to radiation and irradiated potatoes \\ at "Radiation Fair" in Osaka, Japan
}

\begin{abstract}
"Radiation Fair" has been held in summer vacation season in August for more than 10 years in Osaka, the largest city of western Japan, for the purpose of public education and information transfer of radiation and radiation-related technology. We distributed questionnaires to the visitors of the latest "Radiation Fair" held in August 9-16, 1996 to inquire their status toward radiation and irradiated products including irradiated potatoes as well as impression toward the displays. According to the survey results, kids visitors come to know the word "radiation" during elementary school days and seem to gain a definite image toward radiation as their age increase. More than $60 \%$ of the kids visitors were satified with this exhibition as informative. The results also indicated that more than half of the older visitors (16years old and upward) recognized the word of radiation when they were at elementary school and the most significant sources of this information were school lessons and the mass media. Consumers image toward radiation seems to shift to more positive when correct knowledge about radiation is given. Less than half of comsumers did not know irradiated potatoes but the percentage indicating that irradiated potatoes was hazardous was only $5.2 \%$.
\end{abstract}

\section{1.はじめに}

放射線利用技術が一般公衆に受け入れられるため には放射線や放射線関連技術についての正しい知識 普及がまず第一条件となろう。例えば食品照射に関 しては欧米を中心に各地で照射食品の試験販売が行 われ，放射線や照射技術に関して専門知識をもたな い消費者に照射食品に関する情報を効率よく伝える ことに成功している。1993年に報告された，米国の 1,000 人以上の消費者を対象とした大規模な調査か ら，回答者の73\%が食品照射について聞いたことが あり,24\%が食品照射について何らかの知識をもっ ていることが明らかにされた。さらに食品照射によ り得られる利益，またどの機関により食品照射が許
可されるのかを知ったのちには $54 \%$ が非照射の食品 よりも照射された食品を購入したいと回答してい る。

わが国においては20年以上にわたり，ジャガイモ の芽止め照射が行われ，最近では毎年 1 万トン以上 の照射ジャガイモが国内市場で流通している。原子 力発電など原子力に対する国民の意識についてはマ スコミを含めた種々の機関において多くの調査が行 われてきたが，放射線利用や食品照射などの放射線 関連技術に対しては，国内で行われた国際会議やセ ミナーにおける消費者団体の指導者やマスコミ関係 者からの意見発表はあったものの，一般消費者が放 射線や芽止めジャガイモに対してどのような意識を 持っているかについての大規模な調查は行われてい 
なかった。関西地域では我々の研究所も含めた放射 線に関連の深い 9 団体（大阪府立大学先端科学研究 所, (社)大阪ニュークリアサイエンス協会, (社)日本ア イソトープ協会, 日本原子力産業会議関西原子力愍 談会, (社)大阪府放射線技師会, (社)日本原子力学会関 西支部, (财電子科学研究所, (助)日本原子力文化振興 財団，日本原子力研究所）が「みんなのくらしと放 射線」知識普及実行委員会を組織し，小学生を対象 に放射線及びその関連技術の正しい知識普及を目的 として大阪において夏休みの時期に「ラディエーシ ヨンフェアーみんなのくらしと放射線一」を開催し てきた。幸い参加者は年々增加し, 昨年度は 2 万人 を越える入場者数を数えるまでになった。この機会 を利用し，参加者の放射線に対する意識や照射ジャ ガイモに対する印象を知り, 今後さらに効果的な活 動を行う指針とするためにアンケート調査を行っ た。

\section{2.「ラディエーションフェアーみんなのくらしと 放射線一」の概要}

この放射線展の目的はわれわれの身近に存在する 自然放射線や医療や産業において日常的に用いられ ているガンマ線, 電子線, 粒子線など種々の放射線 の基礎知識をパネル展示, 物品展示, ゲーム, クイ ズ，体験工作などによるアトラクションを交えて分 かりやすく知識普及を行うことにある。例年の催し の内容については単なるパネル展示だけにとどまら ず, ゲーム, クイズ, 体験工作などを利用し, 小学 校程度の子どもにも飽きられず，楽しみながら放射 線や放射線利用に関する知識の一端に少しでも触れ てもらえるよう工夫が成されてきた。昨年度は「科 学発見隊 Ray・Kids(レイ・キッズ)」と題し, 100 年前, 放射線物質を発見したベクレル博士が， 1996 年の日本にタイムスリップし,「科学伝道師エック ス」に変装して子どもたちに科学の楽しさや発見の 面白さを伝えるために「科学発見隊 Ray Kids（レ イ・キッズ)」を結成するという設定でフェアを開 催した（Fig. 1)。

参加した子どもたちはまず，「賢者の回廊」と呼 ばれる迷路に挑戦する。迷路内では放射線の基礎知 識を問うクイズに回答し，すべてのクイズに正解で きれば出口に到達できる。次のコーナーは「長老卜 ゲンの遊園地」である。ここでは放射線科学の物知
クで子ども好きの老人，“謎の長老トゲン”がRay ・Kids たちに $\alpha$ 線, $\beta$ 線, $\gamma$ 線などの身の回りに ある種々の放射線について説明する。長老トゲンの 正体は，実は現代によみがえったエックス線の発見 者，レントゲン博士である，という設定である。こ のとき，それぞれの放射線の性質の違いを体感して もらうために, 一定の距離を隔てておいた 3 枚の穴 開き板にボールを投げ，穴を通して 3 枚目の板まで ボールが到達すれば $\gamma$ 線, 二枚目では $\beta$ 線, 一枚 目では $\alpha$ 線と認定する“ガンマー投げゲーム”を 行った。つぎに Ray・Kidsたちは「謎のパワーレ ベルゾーン」に移動する。そこでは岩石, 土垬, 食 品などの身近な暮らしの中にあるものを, 放射線測 定器で計測し, 放射線が自然界や身の回りのごく当 たり前に存在していることを体験する。またインタ ーネットを介してNASAのホームページにアクセ スしたり，百武彗星の写真などの展示を通じて宇宙 の放射線についても学ぶ。一方, 子どもたちととも に入場した父兄に対して, ‘骨密度測定コーナー’, “放射線何でも相談室”を設け，自分の健康状態を チェックできると同時に放射線に関して日頃抱いて いる素朴な疑問について専門家に尋ねられるように 工夫した。つぎに Ray・Kids たちが体験するのは 「サイエンスタウン秘密の大捜索」である。ここに は“元気大通り商店街”と称して放射線による芽止 めジャガイモの展示のほか, 滅菌済み医療用具, 放 射線照射により架橋したタイヤ，ゴルフボールなど のゴム製品，電子線照射により製造された発泡スチ ロール製品など我々の暮らしの中で身近に使用され ている製品が展示された。特に芽止めジャガイモに ついては自由に持ち帰ってよいと表示したため，実

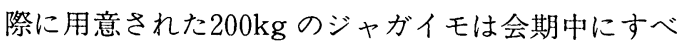
てなくなった。ここでは“大道芸人フ、ォッグス”が 登場し，芽止めジャガイモでお手玉したり，一輪車 に乗ったり，多才な芸で皆を楽しませながら，放射 線の『変身パワー』が，身の回りのいろいろな製品 に利用されていることを説明した。その中で彼は， 霧箱による実験を行い, 参加者は放射線の存在が目 で確かめられることを体験した。最後に Ray・Kids たちは「発見パワークイズ\&科学工作教室」に取り 組み，この会場で学んだ知識を復習する。全問正解 した場合には景品（レイキッズサンバイザー）が進 呈される。科学工作教窒においては風船に蓄えた空 
気の力で前進する“くうき自動車”作りに挑戦する。 出口においてアンケートを記入し, 記念品と交換し てすべてのメニューが終了する。

\section{3. アンケート調查の方法}

アンケートは小中学生以下 (15歳以下) (Fig. 2 1) と高校生以上（16歳以上) (Fig. 2-2) に対象を 分け，それぞれ別個の設問を作成した。それぞれの アンケートには, 男女別, 年齢, 同伴者, 本催しの 情報源，などの基本的質問のほかに，小中学生に対 しては，本催しに参加する前の放射線の知識の有無 や放射線に対するイメージ，面白かったコーナーに ついて設問を設け，高校生以上に対しては，放射線 の認知時期と認知経路及び芽止めジャガイモや食品 に関する設問を加えた。これらを両面に印刷したア ンケート用紙を入り口において参加者に配布し, 記 入された用紙を出口において回収した。8月9日か ら16日までの会期中に 20,154 名が入場し，3,568通 のアンケート (小中学生: 2,153 通, 高校生以上： 1,415名)を回収することができた(回収率17.6\%)。 回答者のうち女性の比率は, 小中学生以上が $52 \%$, 高校生以上が70.5\%で，小中学生以下の参加者のほ とんどが母親同伴であった。参加者の半分以上は“百 貨店の中で偶然本催しの存在を知り, 来場した”と 回答した。

“放射線のことに関してなにがしか聞いたことが ある”と答えた小中学生の回答者の比率は小学校低 学年（ 7 〜歳）では $43 \%$ に過ぎなかったが, 年齢 とともに増加し, 中学生では $94.6 \%$ に達した。本催 しに参加する前，“放射線”という言葉を聞いて何 を連想したかについて質問したところ，小学校低学 年以下では約半数が無回答であったが, 高学年にな るにつれ “レントゲン”, “原子力発電”, “キュリー 夫人”を選択する率が増加し, 中学生ではそれぞれ $22.6 \% ， 44.1 \% ， 16.1 \%$ に達した。一方, “こわい” を連想する回答者の比率は小学生では低学年, 高学 年いずれも $10 \%$ を超えなかったが，中学生になると 14\%まで高まることが明らかとなった。逆に“役に 立つ”, “招もしろい”と回答した比率は小学校, 中 学校ともにおよそ10\%で顕著な変化は見られなかっ た（Fig. 3)。本催しのなかで面白かったコーナー については “長老トゲン”が最も選択率が高かった （26.4\%）が，他に比べて突出したものではなかっ
た。さらに本催しに参加して“放射線のことがよく 分かった”と答えた小中学生の割合は, 小学校低学 年（7〜9歳）では $20.6 \%$ にどまったが，年齢の 上昇とともに増加し, 中学生の参加者では $51.6 \%$ が “よくわかった”と答之，“少しわかった”と答えた 人数をあわせるとほぼ $90 \%$ に達することが明らかと なった。

一方，高校生以上の参加者に“「放射線」という 言葉を初めて聞いたのはいつか”と質問したとこ ろ，59.1\%が “小学生時代”と答え，そのなかの $46.9 \%$ が学校, $40.2 \%$ がスコミ（テレビ，新聞, 雑誌）を通じて知ったと答えた（Fig. 4)。また“放 射線”という言葉を聞いて連想する言葉としては“レ ントゲン”(48.5\%), “原子力発電”(29.5\%), “キュ リ一夫人”(15.1\%) と続き，“こわい”(21.0\%)に ついては中学生（14\%）よりも選択率が少し増加し たものの, 全体的には中学生に対して得られた分布 と大きな違いは見られなかった (Fig. 3 参照)。

さらに高校生以上の参加者に対し, 本催しに参加 する以前に自然放射線の存在を知っていたかどうか について尋ねたところ，64.8\%が“知っていた”と 回答した。“知っていた”と答えた人の放射線から 連想する言葉についてさらに調べると，20\%が放射 線から“役に立つ”, “おもしろい”を連想し, “こ わい”を連想するのは $10 \%$ に過ぎなかったが，“知 らなかった”場合には逆に $20 \%$ のが“こわい”と 答え，放射線に対して肯定的なイメージを持つ割合 は $5 \%$ に落ち込んだ。

次に放射線照射による芽止めジャガイモの存在に ついての知識について尋ねたところ，芽止めジャガ イモに関しては知っていたのは $39 \%$ にどまり，日 本における食品照射の知名度が米国（72\%）に比べ てはるかに低いことが明らかになった。芽止めジャ ガイモの展示と説明パネルを見たあとの印象につい ては $57 \%$ \%゙説明がよく分かった”と回答し， $14.5 \%$ が“食べてみたい”と回答した。しかし34\%は依然 として“説明は理解できたが, 食べる気がしない” と回答した。ただし“放射線照射は有害なので食べ

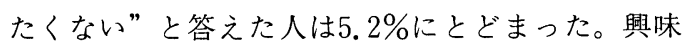
深いことに芽止めジャガイモを知っていた人の $85 \%$ は自然放射線の存在を知っていた。さらに食品につ いて日頃気になることについて尋ねると,“新鮮さ” (50.2\%), “食品添加物” $(42.5 \%)$ が回答の上位を 
占め, “農薬” (24\%), “賞味期限”(21.3\%) がそれ に続き，放射線照射を選んだ回答は $5.8 \%$ に過ぎな かった。本催しの会期中には病原性大腸菌 O-157 株による食中毒が大阪府堺市域において猛威を奮っ ていたのにもかかわらず，“食中毒菌”を選んだ回 答が18\%にとどまった。このことが何を意味するか は今後の検討課題である。

\section{4. 総 括}

本アンケートの結果から，参加者が “放射線” と いう言葉を認知するのは主に小学生の時期であり, その認知経路としては, マスコミに加之, 学校が重 要な役割を担っていることが明らかになった。また 「放射線から連想する言葉は何か」という質問に対 する小中学生の “分からない”を選択した回答，無 回答の比率が年跘が高まるほど減少し, 具体的な連 想語を選ぶ比率が高まることから小学校の間に放射 線のイメージが形成されはじめ, 高校に入学するま でにイメージが確立することが予測される。特に放 射線から“こわい”という言葉を連想するという回 答が, 中学生において増加したことは, 小学校高学 年から中学校にかけての教育が非常に重要なことを 示している。一方, 放射線について何らかの知識(本 調査では自然放射線，芽止めジャガイモに関する知 識）を有する参加者は放射線に対してより好意的な イメージ（“やくにたつ”，“おもしろい”など）を もっている可能性が示唆された。
以上のことから，小中学校の時期に放射線の正し い知識普及を行うことにより，放射線に対する誤っ たイメージの形成が防げ，食品照射を含む放射線利 用に対するパブリックアクセプタンスの形成が進む 可能性が期待できる。現在, 教科書における, 原子 力エネルギー, 放射線関連の記述の不備が, 放射線 教育フォーラム, 原子力学会, 保健物理学会など各 方面から指摘され, 教科書や学習指導要領の改善が 望まれている。今後, 小学校を中心に教育課程, 教 科書を検証し, さらに小学校教員の養成を行ってい る教育大学の教育課程にも調査対象を広げ, 教室で 実際に行われている放射線や原子力エネルギーに関 する教育のどこに不備があるのかを明らかにするこ とにより，より効果的な知識普及システムの開発を 目指したい。

\section{謝辞}

本調査を行うにあたり貴重なご意見を賜った大阪 府立大学先端科学研究所林 善郎教授, 細川 康教 授，「みんなのくらしと放射線」知識普及実行委員 会専門部会のメンバー, 京都大学原子炉実験所西原 英晃教授に感謝の意を表します。またアンケートの 内容について吟味いただいたノートルダム女子大学 住田幸次郎教授に感謝いたします。

（1997年 8 月26日受理） 

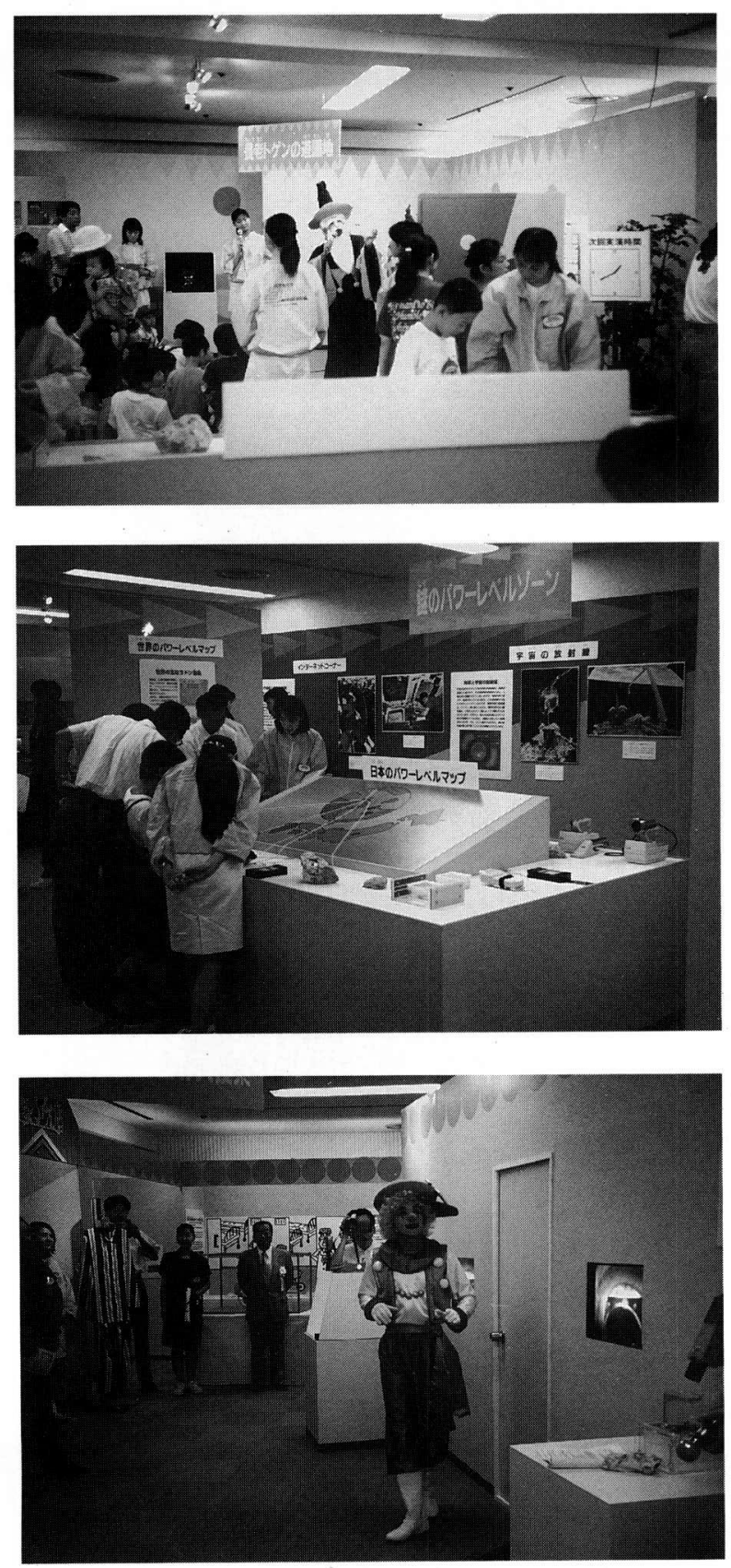

Fig. 1 View of the 1996 Radiation Fair.

Top: "Senior Togen" is talking to Ray Kids.

Center: Ray Kids are measuring natural radiations from various samples in our daily life.

Bottom: Street performer "Fogs" is providing games and acrobatics using irradiated products. 


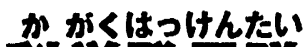 \\ 科学発見厤レイ・キッズ アンケート}

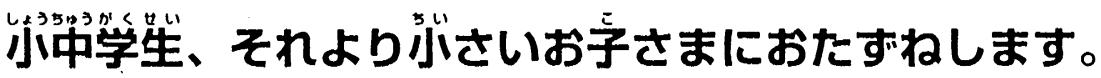

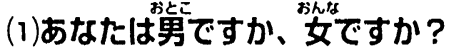

(1)男 (おとこ)

(2)女（おんな）
(2)おいくつですか?

(1)0から6歳

(2)7から9筬

(3)10から12歳

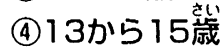

(3)きようは、だれと㫧ましたか？

(1)お父さん

(2)お每さん

(3おじいさん（4)おばあさん

(5)党第、姉妹 (6)お发だち

(7)ひとり

(8)その他

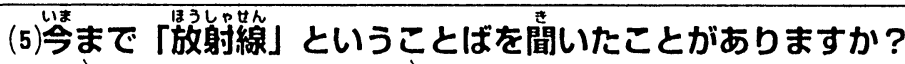

(1)聞いたことがある

(2)聞いたことがない

(4)このイベントは问で知りましたか?

(1)ポスター、チラシ (2)新聞記事

(3)テレビ (4)ラジオ (5)大阪府広報誌

(6)家族や袭だちから間いて

(7)百貨店に来て (8)その他（）

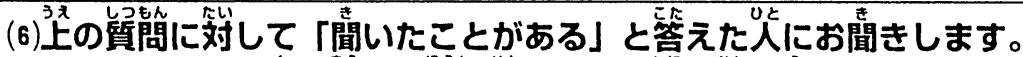
レイ・キッズに来る前は、放射線について阿を思い浮かべましたか?

(1)役に立つ (2)おもしろい (3)こわい (4)きらい (5)わからない (6)原子篦䉓

(7)レントゲン写真 8キュリー夫先 (9)その他（）

(7)おもしろかったコーナーはどれでしたか？

(1)資者の回廊 (2)長老トゲンの遊固地（3蒾のパワーレベルゾーン

(4)サイエンスタウン秘密の大捜采 (5)先気大通り商店街 (6)科学発見教室

(7)その他（）

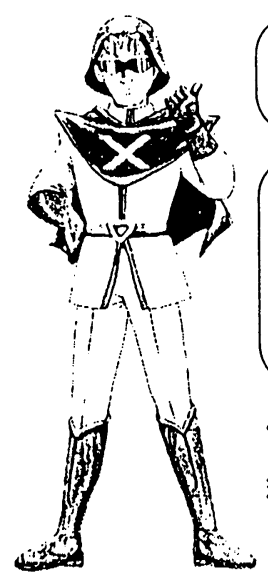

(8)レイ・キッズを見て、綮射線のことがよくわかりましたか?

(1)よくわかった (2)すこしわかった (3)わからなかった

(9)このイベントの䈍想を首由畀に墨いてください。

〈クイズのこたえ〉

科学依道師メの正体は
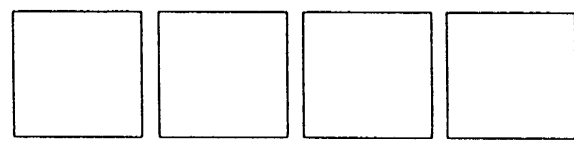

です。

Fig. 2-1 Distributed questionnaire for the junior high and elementary school students and downward 


\section{科学発見隊レイ・キッズ アンケート}

\section{高校生以上の方におたすねします。}

(1)性別は? (1)男性 (2)女性

(2)年歯は? (1)10代 (2)20代 (3)30代 (4)40代 (5)50代 (6)60代 (ㄱ)70代以上

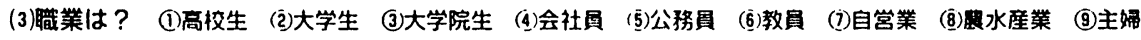
(19册瞕 面その他（）

(4)きようは誰と来ましたか?

(1)お父さん（2)お田さん（3)おしいさん（4)おばあさん（5)兄第、姉妹 (6)友人（7)ひとり

(8)子供、孫(帛)他（）

(5)このイベントは何で知りましたか?

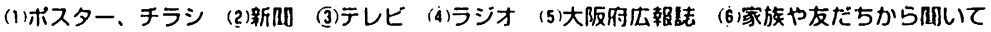

(?)百皆店に来て (B)その他（）

(6)「放射楾」という翼葉をはじめて意識したのはいつ頃からですか?

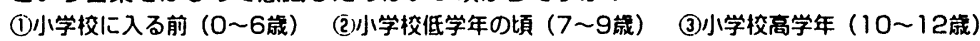

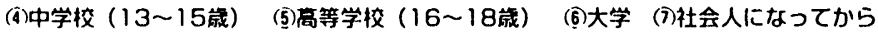

(8)今まで意䧕したことがない

(7)上の睤問に対して(1)〜(7)と答えた方にお間きします。

「放射線」という思葉をはじめて意識したのはどんなときですか？

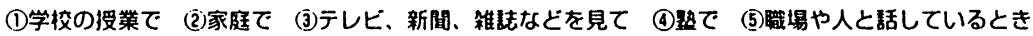
(6)の他 (

(8)レイ・キッスに来る前は、放射線ということばを間いて、问を思い浮かべましたか？

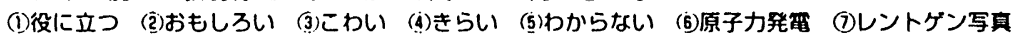

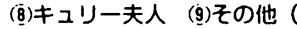
)

(9)大地や宇宙、食物などから自然の放射線を受けていることを知っていましたか？

(1)知っていた (2)知らなかった

(10)ジャガイモの芽止めに放射線が使われていたことを知っていましたか?

(i)知っていた (2)知らなかった

(1)芽止めジャガイモについてどう感じましか？

(1镍明がよくかかった (2)食へてみたい (锁明は理解できたが、食べののは何となく気が進まない

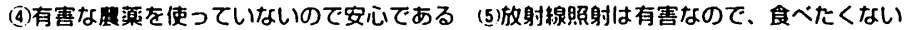

(12)食品について、日頃もっとも気になる点は何ですか？

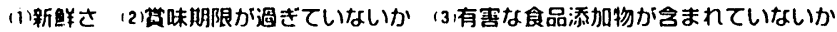

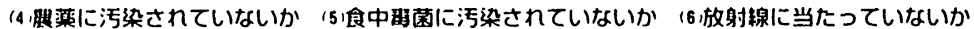

(7)その他（

(13)このイベントの感想を自由に異いてください。

\begin{tabular}{|l|l|}
\hline 々来年、開催予定のイベント情報が必要な方は、ご案内しますので、こ住所とお名前をお量きください。 \\
\hline こ住所 & お名前 \\
\end{tabular}

Fig. 2-2 Distributed questionnaire for the senior high school students and upward. 


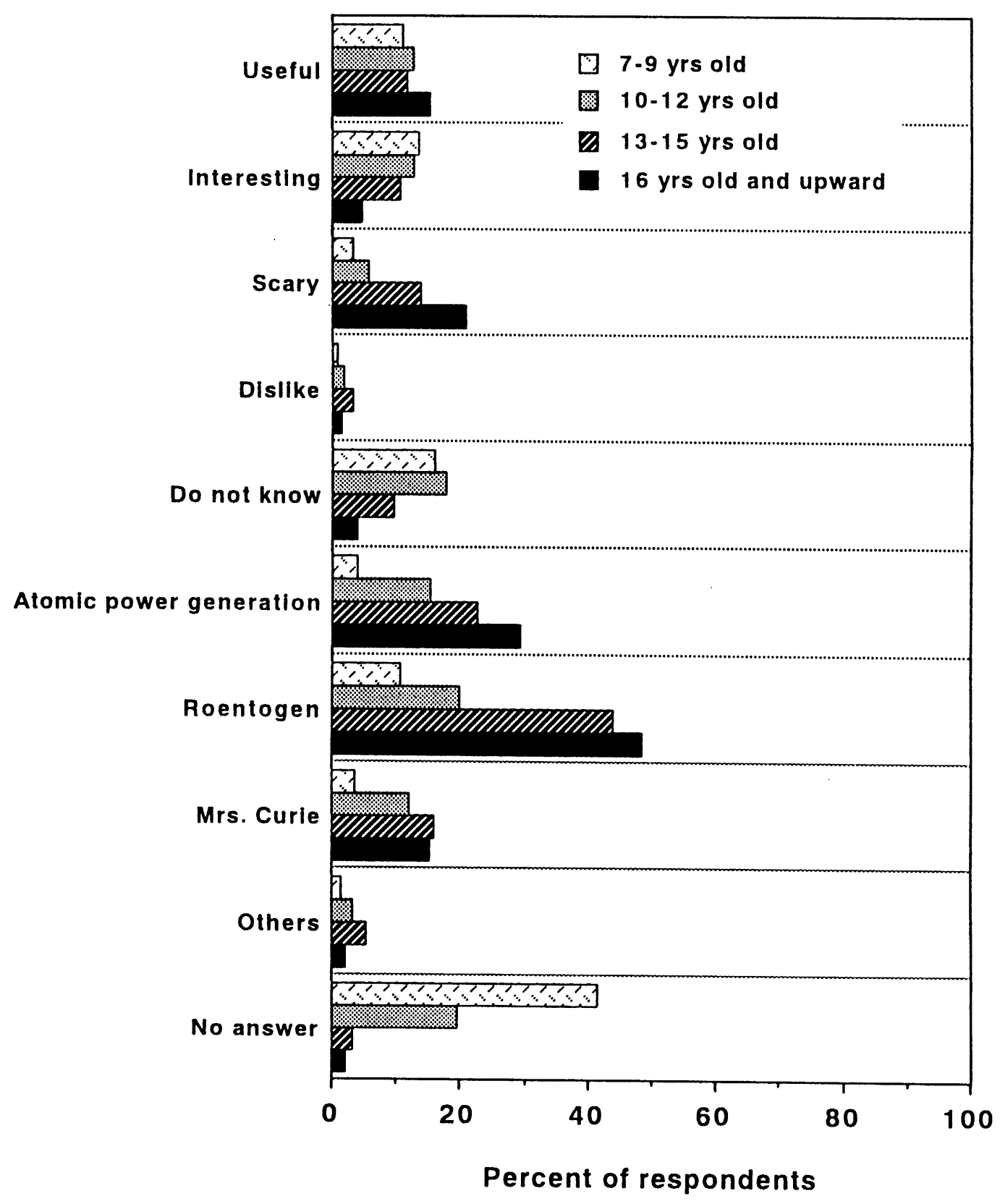

Fig. 3 Closest images associated with "Radiation". 

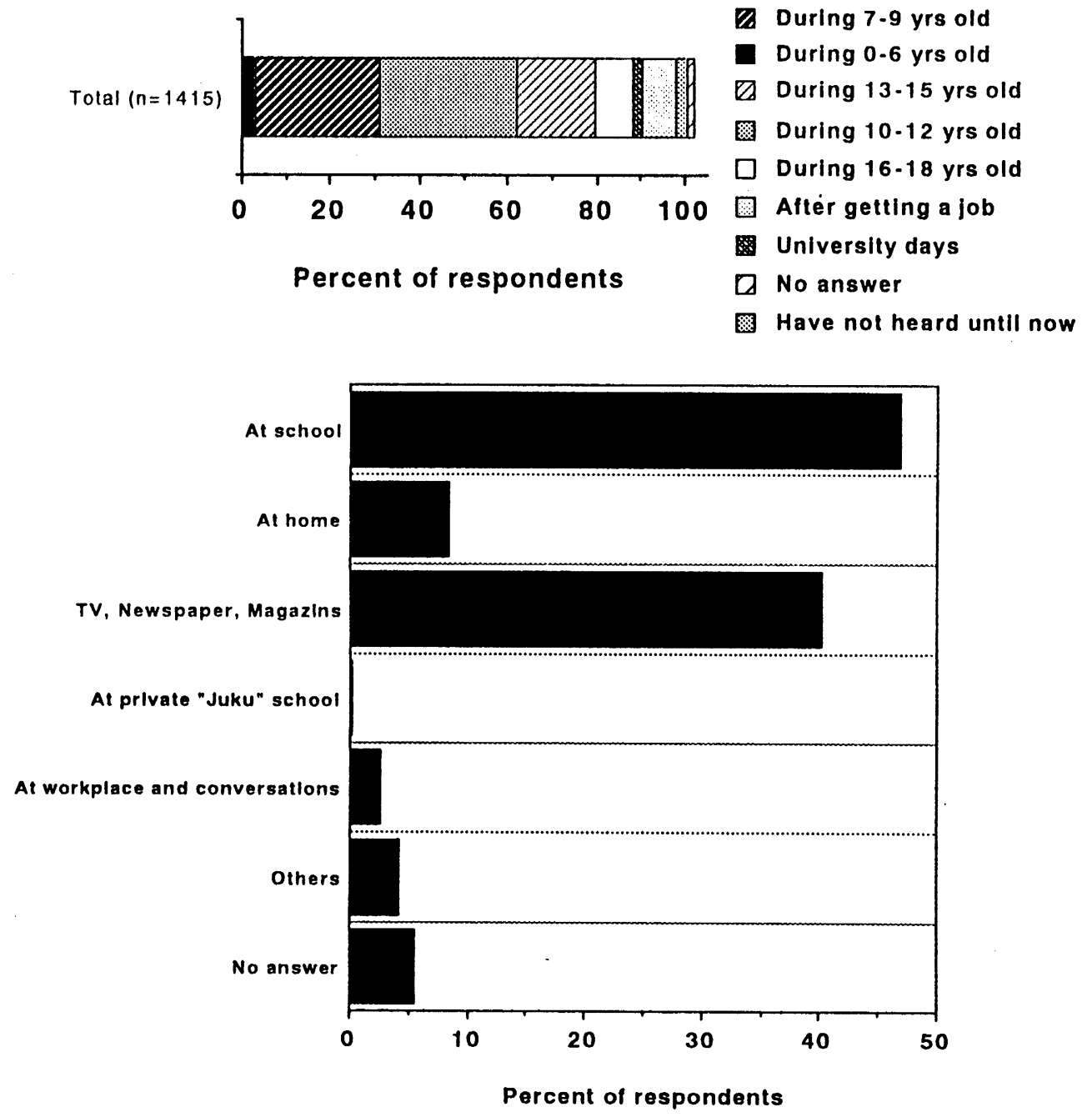

Fig. 4 Distribution of the recogintion time (Top) and sources (Bottom) of "radiation" by 16-year old and upward participants. 